[Research Note]

\title{
Mechanism of $\mathrm{NiMoO}_{4}$ Formation during Oxidative Regeneration of Resid HDS Catalyst
}

\author{
Ryuichiro Iwamoto $^{\dagger 1) *}$, Keisui Matsui ${ }^{\dagger 2)}$, and Atsushi YamaZaKI ${ }^{\dagger 2)}$ \\ ${ }^{\dagger 1)}$ Petroleum Refining Technology Center, Idemitsu Kosan Co., Ltd., 2-1 Anegasaki-kaigan, Ichihara, Chiba 299-0107, JAPAN \\ ${ }^{\dagger 2}$ S) School of Creative Science and Engineering, Dept. of Resources and Environmental Engineering, Waseda University, \\ Ohkubo 3-4-1, Shinjuku-ku, Tokyo 169-8555, JAPAN
}

(Received September 25, 2008)

\begin{abstract}
Aggregation of the active metal components as $\mathrm{NiMoO}_{4}$ during oxidative regeneration of residue hydrodesulfurization catalyst was studied by conventional and micro X-ray diffraction (XRD). The formation of $\mathrm{NiMoO}_{4}$ was observed only on catalyst regenerated above $723 \mathrm{~K}$ by conventional XRD. Distribution of $\mathrm{NiMoO}_{4}$ formation through the section of a catalyst particle was investigated by micro-XRD. The center of the catalyst particle showed higher aggregation of $\mathrm{NiMoO}_{4}$ compared to the outside of the catalyst. These results indicate that $\mathrm{NiMoO}_{4}$ formation is mainly caused by temperature increase inside the catalyst due to the heat accumulation from coke burning. Since the distribution of $\mathrm{NiMoO}_{4}$ was not associated with that of vanadium, which was mainly present on the outside of the catalyst particle, vanadium did not chemically affect the active metal states.
\end{abstract}

\section{Keywords}

Oxidative regeneration, Resid hydrodesulfurization catalyst, Vanadium accumulation,

Nickel molybdenum oxide, Micro X-ray diffraction, Coke burning

\section{Introduction}

The petroleum industry is making great efforts to reduce emissions of pollutants and to build environmentally friendly refineries. One of the most important wastes from refineries is used hydrodesulfurization (HDS) catalyst from the processing of the residue fraction, because a large volume of the catalyst must be exchanged every year due to the relatively higher deactivation rate. Therefore, the regeneration and reuse of resid HDS catalyst is an effective step in the establishment of environmentally friendly refinery. However, the resid HDS catalyst is very difficult to regenerate stably because of the insufficient recovery of activity and physicochemical properties ${ }^{1) \sim 9)}$. More effective regeneration of resid HDS catalyst requires the prevention of $\mathrm{NiMoO}_{4}$ formation. Deactivation during resid HDS has been extensively studied, but the deactivation during oxidative regeneration is less well understood.

The present study investigated the mechanism of $\mathrm{NiMoO}_{4}$ formation using conventional and micro X-ray diffraction (XRD). Micro-XRD is very useful to obtain precise information on local structural changes within a particular catalyst particle, whereas conventional XRD gives only the average structure of the catalyst ${ }^{10)}$.

\footnotetext{
* To whom correspondence should be addressed.

* E-mail: ryuichiro.iwamoto@si.idemitsu.co.jp
}

Therefore, the distribution of $\mathrm{NiMoO}_{4}$ over the catalyst particle was investigated using this technique to elucidate the mechanism of $\mathrm{NiMoO}_{4}$ formation. In addition, the effect of regeneration temperature on the active metal dispersion was also investigated.

\section{Experimental}

\section{1. Catalyst Preparation}

Conventional $\mathrm{NiO}-\mathrm{MoO}_{3}-\mathrm{P}_{2} \mathrm{O}_{5} / \mathrm{Al}_{2} \mathrm{O}_{3}$ catalyst was prepared by impregnating $\gamma$-alumina with $\mathrm{Ni}-\mathrm{Mo}^{-} \mathrm{P}$ solution as described elsewhere ${ }^{11)}$. The catalyst was loaded in a commercial hydrodesulfurization unit for atmospheric residue (ARDS). After presulfiding, the unit was operated to produce fuel oil with sulfur content of $c a .0 .3 \mathrm{wt} \%$ for 1 year. Then, deactivated catalyst samples located near the bottom position were taken from the reactor. The used catalysts were regenerated at a target temperatures from 573 to $723 \mathrm{~K}$ in dry air as well as by commercial processing. The samples were heated up at $10 \mathrm{~K} / \mathrm{min}$ to the target temperature and maintained for $10 \mathrm{~h}$ to eliminate deposited carbon, sulfur and nitrogen.

\section{2. Catalyst Characterization \\ 2. 2. 1. Analysis of Catalyst Composition}

The average composition of the catalyst component and the distribution of the components over the catalyst particle were determined by energy-dispersive X-ray 
spectroscopy (EDS) using a JSM-6360 (JEOL). Average composition was measured with powdered catalyst. The distribution of the catalyst component over the catalyst was measured by scanning the exposed section of catalyst particle from outside to center at $200 \mu \mathrm{m}$ intervals to obtain three measurements. Coke, hydrogen, sulfur and nitrogen on the catalyst were also analyzed by CHN analysis using a CHN/O 2400 analyzer series II (Perkin Elmer Inc.).

\section{2. 2. Conventional XRD Measurement}

The active metal dispersion on the regenerated catalyst was investigated by conventional XRD measurement using a RINT Ultima III (Rigaku Corp.) equipped with a goniometer and a monochromator, using $\mathrm{CuK} \alpha$ radiation at $40 \mathrm{kV}$ and tube current of $30 \mathrm{~mA}$.

\section{2.3. Micro-XRD Measurement}

Micro-XRD was performed using a RINT-RAPID (Rigaku Corp.) with $\mathrm{CuK} \alpha$ radiation at $40 \mathrm{kV}$ and tube current of $30 \mathrm{~mA}$. The diameter of the analysis area was limited to $100 \times 100 \mu \mathrm{m}$ with a collimator size of $0.1 \mathrm{~mm}$. The sample was fixed to 20 degree about the $\omega$-axis and 0 degree about the $\phi$-axis. Micro-XRD patterns were obtained by scanning the exposed section of the catalyst particle from outside to center at $150 \mu \mathrm{m}$ intervals to obtain four measurements.

\section{2. 4. DTA Measurement}

Differential thermal analysis (DTA) was performed with a EXSTAR 600 (SII Nano Technology Inc.) The used catalysts were washed with toluene and preheated at $673 \mathrm{~K}$ under a flow of nitrogen for $2 \mathrm{~h}$. After cooling to room temperature, the catalyst was heated up to $1073 \mathrm{~K}$ at $5 \mathrm{~K} / \mathrm{min}$ under a flow of dry air at $10 \mathrm{~m} / / \mathrm{min}$.

\section{3. Catalyst Activity Measurement}

Thiophene HDS was carried out at atmospheric pressure in a flow type micro reactor. Catalyst samples $(0.3 \mathrm{~g})$ regenerated at different temperatures were sieved at 32 to 64 mesh and packed in the reactor without dilution, and presulfided at $673 \mathrm{~K}$ for $24 \mathrm{~h}$ with $\mathrm{H}_{2} / \mathrm{H}_{2} \mathrm{~S}$ $(90 / 10 \mathrm{vol} \%)$ gas at $50 \mathrm{ml} / \mathrm{min}$. After cooling to $573 \mathrm{~K}$, thiophene was introduced into the reactors at constant pressure $(50$ Torr, 1 Torr $=133.322 \mathrm{~Pa})$ with a hydrogen flow rate of $10 \mathrm{~m} / / \mathrm{min}$. The products were analyzed by gas chromatography after $3 \mathrm{~h}$.

\section{Results and Discussion}

Figure 1 and Table 1 show the carbon, hydrogen, sulfur and nitrogen contents of the catalysts regenerated at different temperatures. These compositions changed drastically depending on the calcination temperature. These components started to decrease above $573 \mathrm{~K}$ and almost disappeared at $673 \mathrm{~K}$. These results basically agree with the findings of continuous temperature programmed oxidation ${ }^{12) ~ 18)}$.

Figure 2 shows the conventional XRD patterns of the resid HDS catalysts regenerated at different temper-
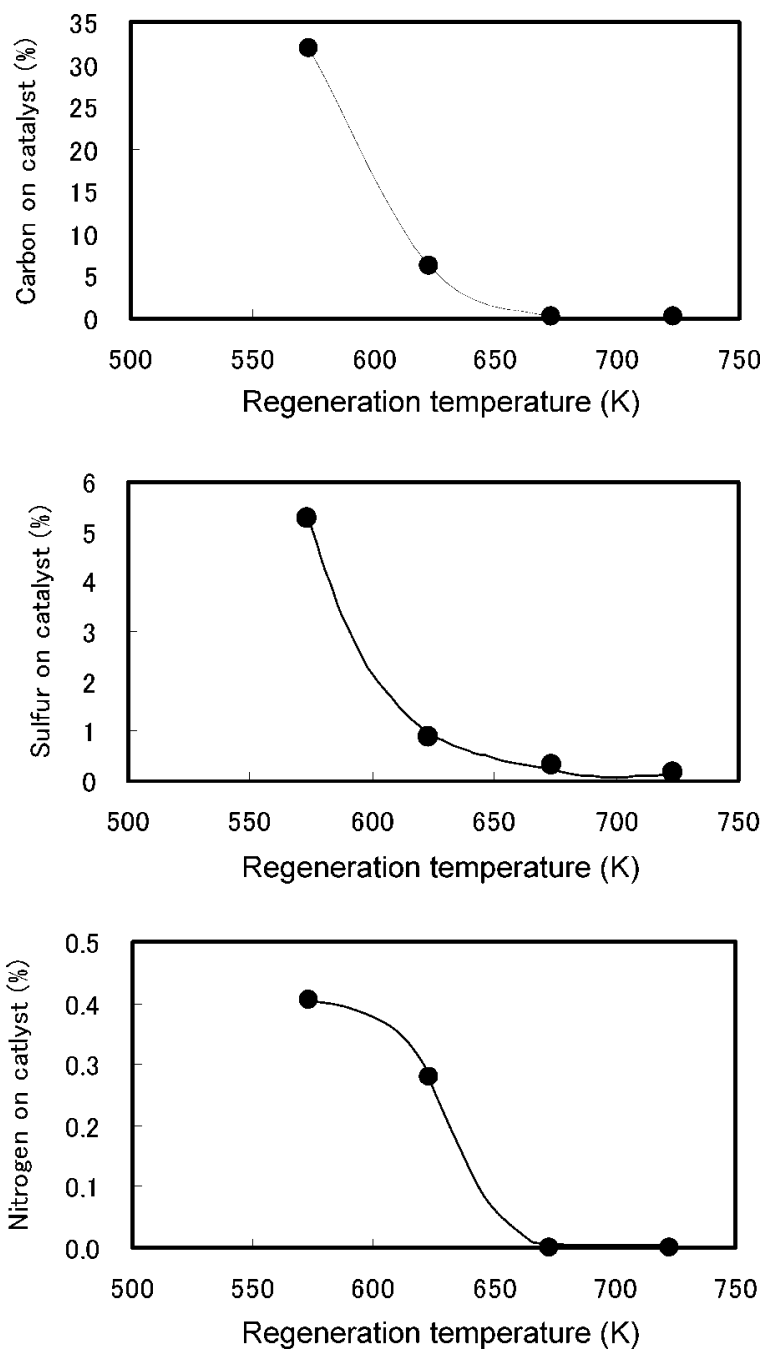

Fig. 1 Effect of Regeneration Temperature on Carbon, Sulfur and Nitrogen Contents of the Catalyst

atures, as well as fresh and used catalysts. The fresh and used catalysts mainly showed a few broad peaks belonging to the $\gamma$-alumina support around 37, 46 and 67 degree/2 $\theta$. The peak for $\mathrm{NiMoO}_{4}$ was absent in these catalysts, indicating the aggregation of the nickel and molybdenum components ${ }^{6,199,20)}$. The regenerated catalysts showed no distinct differences up to $623 \mathrm{~K}$. Therefore, no obvious aggregation of nickel and molybdenum components is likely to occur at this stage. However, the catalyst regenerated at $723 \mathrm{~K}$ showed a clear peak of $\mathrm{NiMoO}_{4}$ around 26 degree/2 $\theta$. Figure 3 shows the thiophene HDS activity for the catalysts regenerated at different temperatures. The thiophene HDS activity increased with higher regenerated temperature up to $673 \mathrm{~K}$ due to coke elimination, and then started to decrease above $723 \mathrm{~K}$. This finding corresponds well to the aggregation of active metals as shown in Fig. 2.

Figure 4 shows the micro-XRD patterns for the sec- 
Table 1 Carbon, Sulfur and Nitrogen Contents of the Regenerated Catalyst

\begin{tabular}{|c|c|c|c|c|c|c|c|c|c|}
\hline & \multirow{3}{*}{ Used catalyst } & \multicolumn{8}{|c|}{ Regeneration temperature } \\
\hline & & \multicolumn{2}{|c|}{$573 \mathrm{~K}$} & \multicolumn{2}{|c|}{$623 \mathrm{~K}$} & \multicolumn{2}{|c|}{$673 \mathrm{~K}$} & \multicolumn{2}{|c|}{$723 \mathrm{~K}$} \\
\hline & & $5 \mathrm{~h}$ & $10 \mathrm{~h}$ & $5 \mathrm{~h}$ & $10 \mathrm{~h}$ & $5 \mathrm{~h}$ & $10 \mathrm{~h}$ & $5 \mathrm{~h}$ & $10 \mathrm{~h}$ \\
\hline $\mathrm{C}$ & 36.1 & 36.9 & 32.0 & 21.9 & 6.3 & 0.5 & 0.3 & 0.1 & 0.2 \\
\hline $\mathrm{H}$ & 3.8 & 2.9 & 2.6 & 1.7 & 1.5 & 1.4 & 1.0 & 1.3 & 1.2 \\
\hline $\mathrm{N}$ & 0.3 & 0.4 & 0.4 & 0.3 & 0.3 & 0.0 & 0.0 & 0.0 & 0.0 \\
\hline $\mathrm{S}$ & 5.8 & 6.1 & 5.3 & 3.1 & 0.9 & 0.4 & 0.3 & 0.2 & 0.2 \\
\hline
\end{tabular}

Concentrations were calculated based on the weight of fresh catalyst as $100 \%$.

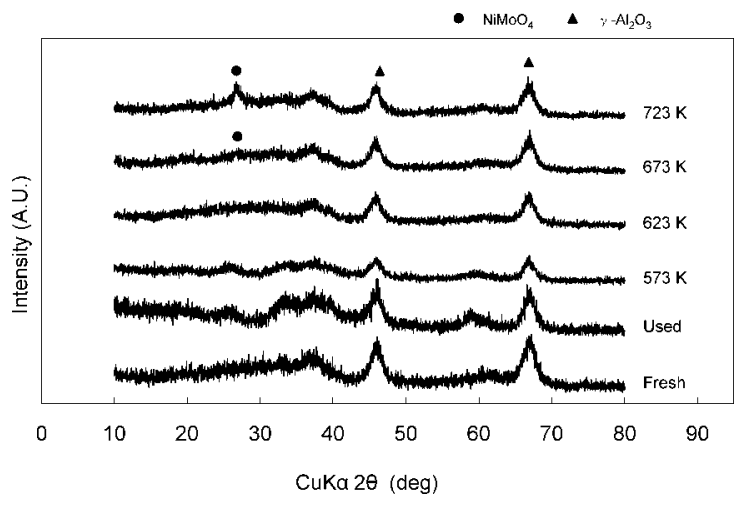

(a) Fresh catalyst, (b) Used catalyst, (c) Catalyst regenerated at $573 \mathrm{~K}$, (d) Catalyst regenerated at $623 \mathrm{~K}$, (e) Catalyst regenerated at $673 \mathrm{~K}$, (f) Catalyst regenerated at $723 \mathrm{~K}$.

Fig. 2 X-ray Diffraction Patterns of the Fresh, Used and Regenerated Catalysts Calcined for $10 \mathrm{~h}$

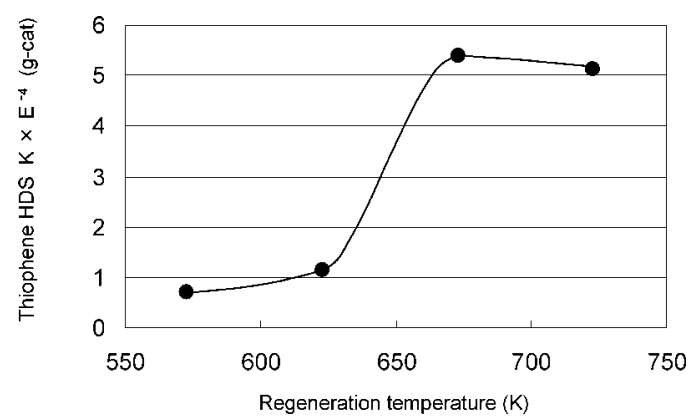

Fig. 3 Thiophene HDS Activity of Catalysts Regenerated at Different Temperatures

tion of a catalyst particle containing average $2.8 \mathrm{wt} \%$ vanadium and regenerated at $723 \mathrm{~K}$. The peak of $\mathrm{NiMoO}_{4}$ was observed at 26 degree/ $2 \theta$ over the section of the catalyst. The peaks of alumina were also obtained around 46 and 67 degree $/ 2 \theta$. A peak at 43 degree/2 $\theta$ was assigned to the (1_1_3) plane of $\alpha-\mathrm{Al}_{2} \mathrm{O}_{3}$. This $\alpha-\mathrm{Al}_{2} \mathrm{O}_{3}$ might be very orientated, as this was not clearly observed in the conventional XRD pattern. To investigate the $\mathrm{NiMoO}_{4}$ distribution, the amount of $\mathrm{NiMoO}_{4}$ over the catalyst particle was plotted as the intensity ratio of $\mathrm{NiMoO}_{4}$ peak $/ \mathrm{Al}_{2} \mathrm{O}_{3}$ peak in Fig. 5(a). The result clearly indicates that the forma-

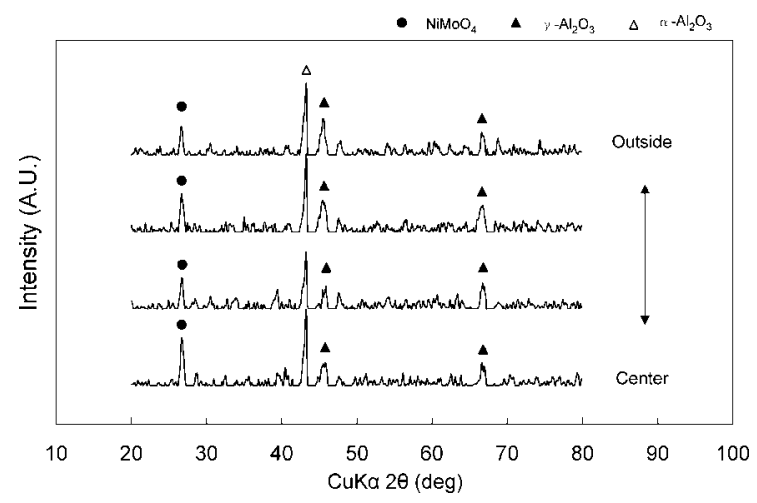

Fig. 4 Micro X-ray Diffraction Patterns from the Outside to the Center of the Regenerated Catalyst Particle

tion of $\mathrm{NiMoO}_{4}$ increased linearly towards the center of the catalyst particle.

No evidence for the aggregation of nickel and molybdenum components was observed in the used catalyst or the catalyst regenerated below $673 \mathrm{~K}$, as shown in Fig. 2. The formation of $\mathrm{NiMoO}_{4}$ was only observed above $723 \mathrm{~K}$ and tended to increase toward the center of the catalyst particle, where heat release may be worse compared with the outside of the catalyst. Therefore, the aggregation of $\mathrm{Ni}$ and Mo must be related to the temperature increase.

To confirm the above discussion more theoretically, the effect of coke burning on the catalyst temperature was calculated. Oxidative regeneration can be described by the following.

$$
\begin{aligned}
& \mathrm{C}+1 / 2 \mathrm{O}_{2} \rightarrow \mathrm{CO}+394 \mathrm{~kJ} \\
& \mathrm{H}_{2}+1 / 2 \mathrm{O}_{2} \rightarrow \mathrm{H}_{2} \mathrm{O}+243 \mathrm{~kJ}
\end{aligned}
$$

If the $\mathrm{H} / \mathrm{C}$ molar ratio of coke on the catalyst is 0.8 , as seen in Table 1, and the specific heat of alumina based catalyst is $1.1 \mathrm{~kJ} / \mathrm{kg} \cdot \mathrm{K}^{21)}, 1 \mathrm{wt} \%$ of coke burning in adiabatic reaction can increase the temperature of the catalyst by about $40 \mathrm{~K}$. Therefore, rapid coke burning and heat release restriction might cause the aggregation of nickel and molybdenum at higher regeneration temperatures.

Figure 5(b) also shows the distribution of vanadium over the section of the catalyst particle measured by 

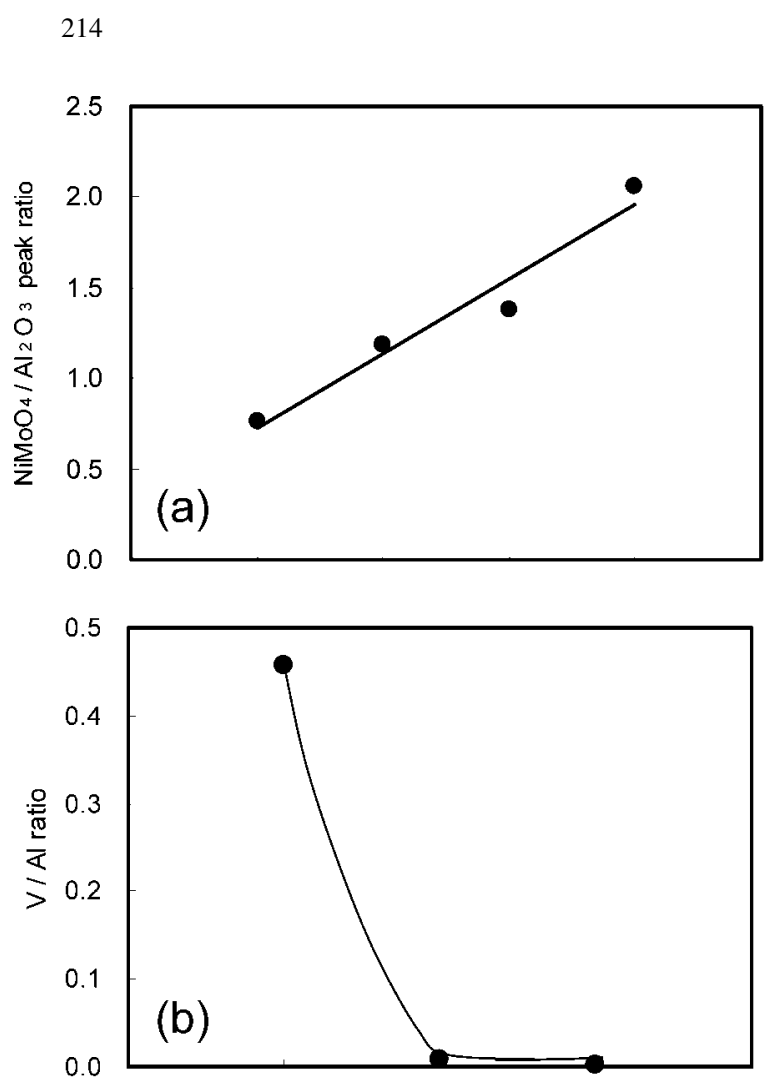

Outside

Center

(a) $\mathrm{NiMoO}_{4} / \mathrm{Al}_{2} \mathrm{O}_{3}$ peak intensity ratio calculated from micro-XRD, (b) Vanadium content measured by EDS.

Peaks of $\mathrm{NiMoO}_{4}$ and $\mathrm{Al}_{2} \mathrm{O}_{3}$ were assigned at 26 and 46 degree/2 $\theta$, respectively.

Fig. 5 Distribution of $\mathrm{NiMoO}_{4}$ and Vanadium over the Catalyst Particle

EDS. As the vanadium is present mainly outside the catalyst, the amount of $\mathrm{NiMoO}_{4}$ formation was not correlated with the position of the vanadium. This finding does not agree with the previous observation that $\mathrm{NiMoO}_{4}$ formation during regeneration is correlated with the vanadium content ${ }^{9)}$. Therefore, the presence of vanadium may not directly affect the aggregation of nickel and molybdenum through chemical interaction. However, vanadium may affect $\mathrm{NiMoO}_{4}$ formation indirectly as follows.

1) Vanadium acts as an oxidation catalyst to accelerate coke burning, resulting in higher temperatures inside the catalyst particle, while outside of the catalyst particle cools down.

2) Higher accumulation of vanadium on the catalyst is associated with less refractory coke, located at the upper part of the reactor and exposed to lower reaction temperatures ${ }^{12) \sim 18)}$. Therefore, coke burning is easier and leads to higher temperatures inside the catalyst particle.

3) Pore mouth plugging by vanadium prevents heat re- lease from inside the catalyst.

In fact, the formation of $\mathrm{NiMoO}_{4}$ is also observed on regenerated HDS catalyst for the distillation fraction, which contains no vanadium ${ }^{12), 19)}$. This also may suggest that vanadium is indirectly involved in $\mathrm{NiMoO}_{4}$ formation.

\section{Conclusion}

Aggregation of active metal components as $\mathrm{NiMoO}_{4}$ during oxidative resid HDS catalyst regeneration was investigated using conventional and micro-XRD.

The findings were as follows.

(i) $\mathrm{NiMoO}_{4}$ formation is only observed with regeneration above $723 \mathrm{~K}$.

(ii) $\mathrm{NiMoO}_{4}$ preferentially forms inside the catalyst particle.

(iii) Vanadium does not chemically affect the states of the active metal, but may be indirectly related with $\mathrm{NiMoO}_{4}$ formation.

(iv) Increased temperature inside the catalyst due to the heat released by coke burning might be the main factor causing active metal aggregation during regeneration.

Therefore, aggregation of active metals might be prevented with milder regeneration conditions such as lower temperature and lower heating rate.

\section{Acknowledgments}

This study was partly carried out under the auspices of the Japan Petroleum Energy Center (JPEC).

\section{Reference}

1) Trimm, D. L., "Catal. in Petroleum Refining 1989," Elsevier, Amsterdam (1990), p. 41.

2) Kim, C. S., Massoth, F. E., Furimsly, E., Fuel Processing Technol., 32, 39 (1992).

3) Furimsky, E., Massoth, F. E., Catal. Today, 17, 537 (1993).

4) Marinković-Neduěin, R., Bošković, G., Kiš, E., Lomić, G., Hantsche, H., Mićic, R., Pavlović, P., Appl. Catal. A: General, 107, 133 (1994)

5) Teixeira da Silva, V. L. S., Grety, R., Schmal, M., Ind. Eng. Chem. Res., 331692 (1994).

6) Madeley, R. A., Wanke, S. E., Appl. Catal., 39, 295 (1988).

7) Guibard, L., Kressmann, S., Morel, F., Harle, V., Dufresne, P., Hydr. Eng., 30, 54 (2000).

8) Dufresne, P., Appl. Catal. A: General, 322, 67 (2007).

9) Iwamoto, R., Kagami, N., J. Jpn. Petrol. Inst., 50, (3), 147 (2007).

10) Iijima, M., Brantley, W. A., Baba, N., Alapati, S. B., Yuasa, T., Ohno, H., Dental materials, 23, (9), 1051 (2007).

11) Iwamoto, R., Kagami, N., Sakoda, Y., Iino, A., J. Jpn. Petrol. Inst., 48, (6), 351 (2005).

12) George., Z. M., Mohammed, P., Tower, R., Proc. 9th Int. Congr. Catal., 1988, 230.

13) Zeuten, P., Jacobson, A. C., 10th North American Meeting of the Catalyst Society, Dearborn, MI, 1989, PD02.

14) Bartholdy, J., Zeuthen, P., Massoth, F. E., Appl. Catal., 129, 33 (1995).

15) Zeuthen, P., Bartholdy, J., Massoth, F. E., Appl. Catal., 129, 43 
(1995).

16) Zeuthen, P., Cooper, B. H., Clark, F. T., Arters, D., Ind. Eng. Res., 34, 755 (1995).

17) Furimsky, E., Nielsen, M., Jurasek, P., Energy Fuel, 9, 439 (1995).

18) Matsushita, K., Hauser, A., Marafi, A., Koide, R., Stanislaus, A.,
Fuel, 83, 1031 (2004).

19) Oh, E-S., Park, Y-C., Lee, I-C., Rhee, H-K., J. Catal., 172, 314 (1997).

20) Brito, J. L., Laine, J., Appl. Catal., 72, L13 (1991).

21) "Handbook of the Soc. of Chem. Eng. Japan," ed. by Hashimoto, K., Maruzen, Tokyo (1999).

要旨

\section{重油脱硫触媒の再生における $\mathrm{NiMoO}_{4}$ 生成機構}

岩本 隆一郎 ${ }^{\dagger 1}$, 松井 景水 ${ }^{\dagger 2}$, 山嵪 淳司 ${ }^{\dagger 2}$

†1) 出光興産 (株) 技術部 石油技術センター, 299-0107 千葉県市原市姉崎海岸2-1

†2) 早稲田大学創造理工学部環境資源工学科, 169-8555 東京都新宿区大久保3-4-1

重油脱硫触媒の再生における $\mathrm{NiMoO}_{4}$ 生成機構について, 一 般的な粉末 $\mathrm{X}$ 線回折測定とマイクロ X 線回折測定により解析 した。一般的な粉末 $\mathrm{X}$ 線回折測定からは $\mathrm{NiMoO}_{4}$ の生成は再生 温度 $723 \mathrm{~K}$ 以上でのみ観測された。さらに, 触媒粒子断面内の $\mathrm{NiMoO}_{4}$ の生成分布をマイクロ X 線回折により測定した結果, 粒子中心部の方が外周部よりも $\mathrm{NiMoO}_{4}$ 生成が多かった。これ
らの結果は $\mathrm{NiMoO}_{4}$ の生成が触媒内部におけるコーク燃焼熱蓄 積による温度上昇が主原因であることを示唆している。また， 重油脱硫触媒では主にバナジウムは外周部に存在しており, $\mathrm{NiMoO}_{4}$ の分布とは一致していないことから, バナジウムの化 学的作用は $\mathrm{NiMoO}_{4}$ の凝集の主原因ではないと考えられる。 